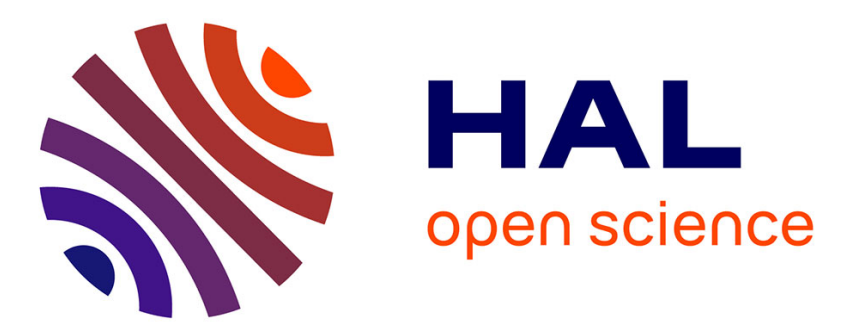

\title{
Removal of nickel and cadmium from aqueous solutions by sewage sludge ash: study in single and binary systems
}

\author{
Zouhair Elouear, Jalel Bouzid, Nesrine Boujelben
}

\section{To cite this version:}

Zouhair Elouear, Jalel Bouzid, Nesrine Boujelben. Removal of nickel and cadmium from aqueous solutions by sewage sludge ash: study in single and binary systems. World Wide Workshop for Young Environmental Scientists: 2010, May 2010, Arcueil, France. hal-00521318

\section{HAL Id: hal-00521318 \\ https://hal.science/hal-00521318}

Submitted on 27 Sep 2010

HAL is a multi-disciplinary open access archive for the deposit and dissemination of scientific research documents, whether they are published or not. The documents may come from teaching and research institutions in France or abroad, or from public or private research centers.
L'archive ouverte pluridisciplinaire HAL, est destinée au dépôt et à la diffusion de documents scientifiques de niveau recherche, publiés ou non, émanant des établissements d'enseignement et de recherche français ou étrangers, des laboratoires publics ou privés. 


\title{
Removal of nickel and cadmium from aqueous solutions by sewage sludge ash: study in single and binary systems
}

\author{
Zouhair ELOUEAR $^{\text {a }}$, J. BOUZID $^{\text {a }}$, N. BOUJELBEN ${ }^{\text {a* }}$
}

a. Laboratoire Eau Energie et Environnement, département de génie géologique, Ecole Nationale d'Ingénieurs de Sfax, BP W 3038 Sfax Tunisie.

Zouhair Elouear: zouheir.elouaer@tunet.tn

Jalel Bouzid : Jalel.bouzid@tunet.tn

Nesrine Boujelben: nesrine.boujelben@tunet.tn

\begin{abstract}
The sewage sludge ash can potentially be used for the removal of metal ions from wastewater due to its similar chemical composition to that of fly ash. The aim of this work was to investigate the adsorptive characteristics of this material including specific surface area and $\mathrm{pH}$ of zero point of charge (pHZPC) and to assess the possibility of removing nickel and cadmium from aqueous solutions by this sorbent. The effects of agitation time, $\mathrm{pH}$, initial metal ion concentration and temperature on the removal of these metals were studied. In order to study the sorption isotherm, two equilibrium models, the Langmuir and Freundlich isotherms, were analyzed. The effect of solution $\mathrm{pH}$ on the adsorption onto sewage sludge ash was studied in the $\mathrm{pH}$ range from 2 to 8 . The adsorption was endothermic and the computation of the parameters, $\Delta \mathrm{H}^{\circ}, \Delta \mathrm{S}^{\circ}$ and $\Delta \mathrm{G}^{\circ}$, indicated that the interactions were thermodynamically favourable. Experiments with $\mathrm{Ni}$ and $\mathrm{Cd}$ adsorption measured together showed that $\mathrm{Cd}$ severely interfered with $\mathrm{Ni}$ adsorption to sewage sludge ash and vice versa under the conditions of the two coexisted ions adsorption.
\end{abstract}

\section{Keywords}

Adsorption, Cadmium, Nickel, Sewage sludge ash, Binary mixtures.

\section{INTRODUCTION}

Metal ions have become an ecotoxicological hazard of prime interest and increasing significance, because of their accumulation in living organisms (Karabulut et al., 2000). Both Ni(II) and $\mathrm{Cd}(\mathrm{II})$ are present in effluents of a large number of industries. People often suffer from allergy due to exposure to nickel-containing materials and the carcinogenic effects of nickel have also been well documented (ATSDR, 2003). Nickel is a toxic metal ion that is widely used in silver refineries, electroplating, zinc base casting and storage battery industries (Kadirvelu et al., 2003). The chronic toxicity of nickel to humans and the environment has been well documented. For example, high concentration of nickel (II) causes cancer of lungs, nose and bone. Cadmium $(\mathrm{Cd}(\mathrm{II}))$ is a non-essential and a non-biodegradable metal ion which slowly accumulates in the body of living creatures, usually through food chain (Srivastava et al., 2006). Hence, removal of cadmium and nickel from water and wastewater assumes importance. The conventional methods for metal ions removal from water and wastewater include oxidation, reduction, precipitation, membrane filtration, ion exchange and adsorption. Among all, adsorption is highly effective and economical. Though the use of commercial activated carbon is a well-known adsorbent for the removal of metal ions from water and wastewater, the high cost of activated carbon limits its use as an adsorbent in developing countries. Hence, several research workers used different low-cost adsorbents such as coconut coir pith (Kadirvelu et al., 2003), sawdust (Wilson et al., 2001), 
sludge ash (Pan et al., 2003), banana pith (Low et al., 1995), activated phosphate rock (Sarioglu et al., 2005), vermiculite (Malandrino et al., 2006), and montmorillonite (Boonfueng et al., 2006). In spite of several researchers adopted various low-cost adsorbents there is still a need to develop suitable adsorbents for the removal of copper and nickel from aqueous solutions.

Recent studies have shown that fly ash is a valuable and desirable additive to cement concrete and it has also been used effectively in many other areas such as soil amendment and fillers (Beaver, 1995; Pratt, 1990; Brendel, 1995). Some research articles reported that alkaline fly ash can serve as stabilizer or binding reagent for the fixing of metal ions and nutrients contained in hazardous wastes and organic wastes (Lin and His, 1995; Vincini et al., 1994; Eiceman and Vandiver, 1983). Many researchers have reused fly ashes as good and inexpensive adsorbent for metal ions, organic compounds especially phenolic compounds, dyes and other organic matters in waters (Cho et al., 2005; Kao et al., 2000; Kumar et al., 2005; Wang and Wu, 2006). Fly ash effectiveness has been reported in the neutralization of soil acidity and help in increasing the availability of certain nutrients in the soil, and reduction of plant parasitic nematodes in soil (Adriano et al., 1980; Elseewi et al., 1980).

In Tunisia, with the development of the wastewater treatment industry, the amount of the residual sewage sludge increased very rapidly. Many reports have appeared on preparation of adsorbent derived from sewage sludge (Chiang et al., 1987; Bashkova et al., 2001; Bagreev et al., 2001). The recycling and the re-using of wastes have energy efficient, environmentally friendly and cost-effective advantages. To the author's knowledge, in Tunisia the problem of this waste product is still not yet solved. The goal of this work is to investigate the feasibility of using adsorbent derived from sewage sludge by incineration for the removal of $\mathrm{Cd}^{2+}$ and $\mathrm{Ni}^{2+}$ from aqueous solution in single and binary system by varying parameters of $\mathrm{pH}$, agitation time, metal ions concentration and temperature.

\section{EXPERIMENTAL}

The sewage sludge sample used in this study was collected from Municipal Community Waste Water Treatment Plant in the south of Tunisia (Sfax city). The sampled dewatered sludge cake was first burned in a modular incinerator at $600^{\circ} \mathrm{C}$ for 2 hours to provide incineration ash and then finely ground by a ball mill. The ground of sewage sludge ash sample was further screened by $100 \mu \mathrm{m}$ sieve. The finer part of this ash passing through the $100 \mu \mathrm{m}$ sieve was collected, tested, and used in the following experiments. The average diameter of the used adsorbent particle was around $60 \mu \mathrm{m}$.

The specific surface area of sewage sludge ash sample was determined by a BET- $\mathrm{N}_{2}$ surface area analyzer (Model QS-7, Quantachrome Co.,Greenvale, NY), and it was found to be $50.85 \mathrm{~m}^{2} / \mathrm{g}$. The average pore diameter was $39.40 \AA$. This sorbent was characterized using:

- Scanning electron microscope (SEM) (Philips XL30) and energy dispersive X-ray analysis (EDAX) (Philips EDAX9100) were used to characterize the ash sample for constituent and morphology. The working tension was $30 \mathrm{kV}$.

- X-Ray diffraction: using an X-ray diffractometer (Siemens, Germany) with $\mathrm{CuK} \alpha$ radiation $(\lambda=0.154 \mathrm{~nm})$. Scans were conducted from 0 to $60^{\circ}$ at a rate of $2 \theta$ per min.

The $\mathrm{pH}$ of zero point of charge (pHzpc) was determined by adding a known amount of adsorbent $(0.1 \mathrm{~g})$ to a series of bottles that contained $50 \mathrm{~mL}$ of deionised water. Before adding the adsorbent, the $\mathrm{pH}$ of the solutions was adjusted to be in the range of 1.0-9.0 by the addition of either $0.1 \mathrm{M} \mathrm{HNO}_{3}$ or $0.1 \mathrm{M} \mathrm{NaOH}$. These bottles were then rotated for $1 \mathrm{~h}$ in a shaker and $\mathrm{pH}$ values were measured at the end of the test. The $\mathrm{pH}$ of the suspensions is represented as a function of the initial $\mathrm{pH}$ of the solutions. The curve obtained theoretically cross the bisector of axes at the point of zero charge (Bouzid et al., 2008).

Batch experiments included: the kinetic studies, $\mathrm{pH}$ effect and sorption isotherms. 
Sorption experiments for the kinetic study were conducted as follow: $1 \mathrm{~g} / \mathrm{L}$ sorbent slurries and metal ion of concentration $100 \mathrm{mg} / \mathrm{L}$ of $\mathrm{Ni}^{2+}$ (obtained from Nickel chloride hexahydrate $\mathrm{NiCl}_{2} 6 \mathrm{H}_{2} \mathrm{O}$ ) or $\mathrm{Cd}^{2+}$ (obtained from cadmium sulphate octatahydrate $\left(\mathrm{CdSO}_{4} 8 \mathrm{H}_{2} \mathrm{O}\right.$ ) were kept in a shaker at room temperature. The solution $\mathrm{pH}$ was adjusted to 6 with $1 \mathrm{M} \mathrm{HNO}_{3}$ and $1 \mathrm{M} \mathrm{NaOH}$. The suspensions were stirred for different time intervals $(1-360 \mathrm{~min})$. The solutions were filtered through a $0.45 \mu \mathrm{m}$ membrane filter (MFS). The metal ions concentration was determined using a flame atomic absorption spectrophotometer (HITACHI Z- 6100) by using air-acetylene flame. Analytical errors were estimated to be of the order of 3\%. All the experiments were duplicated to assure the veracity of experimental results.

To determine the influence of $\mathrm{pH}$, experiments were performed at various initial $\mathrm{pH}$, ranging between $2-8$. Initial concentration of $100 \mathrm{mg} / \mathrm{L}$ of nickel or cadmium and $10 \mathrm{~g} / \mathrm{L}$ of sorbent per $100 \mathrm{~mL}$ of solution were used. The suspensions were stirred for 2 hours.

For single metal-sorbent systems, initial metal ion concentration was varied from 10 to 100 $\mathrm{mg} / \mathrm{L}$. In binary metal ion mixture-sorbent systems, for each initial concentration of $\mathrm{Ni}^{2+}$ solution, viz., $10,30,50,70$, and $100 \mathrm{mg} / \mathrm{L}$, the cadmium concentration was varied in the range of $30-100 \mathrm{mg} / \mathrm{L}$ (viz., 30, 50 and $100 \mathrm{mg} / \mathrm{L}$ ). The $\mathrm{pH}$ of the solutions was maintained at 6 . This $\mathrm{pH}$ was found to be the optimum on the basis of batch tests carried out to determine the effect of $\mathrm{pH}$ on adsorption capacity of sewage sludge ash for metal ions.

The sorption equilibrium data of cadmium and nickel on sewage sludge ash were analysed in terms of Langmuir and Freundlich isotherm model (Glasstone, 1981).

The Langmuir sorption isotherm equation is given as follow:

$$
q_{e}=\frac{q_{\max } b C_{e}}{\left(1+b C_{e}\right)}
$$

On linearization it becomes:

$$
\frac{1}{q_{e}}=\frac{1}{q_{\max }}+\frac{1}{q_{\max } b C_{e}}
$$

Where $q_{e}$ is the metal ions concentration on the adsorbent at equilibrium (mg of metal ion $/ \mathrm{g}$ of adsorbent), $q_{\max }$ is the maximum metal uptake per unit mass of adsorbent ( $\left.\mathrm{mg} / \mathrm{g}\right) . b$ is Langmuir constant $(\mathrm{L} / \mathrm{mg})$ related to energy of adsorption which reflects quantitatively the affinity between the adsorbent and metal ions. The values of $q_{\max }$ and $b$ are the characteristics of the Langmuir model and can be calculated from the intercept and slope of the linear plot, with $1 /\left(q_{e}\right)$ versus $1 / \mathrm{Ce}$.

The Freundlich isotherm equation is given as follow:

$$
q_{e}=K_{f} C_{e}^{1 / n}
$$

It can be written in the linear form as given below:

$$
\ln q_{e}=\ln K_{f}+\frac{1}{n} \ln C_{e}
$$

Where $\mathrm{K}_{\mathrm{f}}$ and $n$ are Freundlich constants, indicating the adsorption capacity and the adsorption intensity respectively. Freundlich constants $k_{\mathrm{F}}$ and $n$ can be calculated from the slope and intercept of the linear plot, with $\log \left(q_{e}\right)$ versus $\log C$ e.

In order to determine the effect of temperature on adsorption phenomenon, isotherms were established at 10,20 and $40^{\circ} \mathrm{C}$. 


\section{RESULTS AND DISCUSSION}

\section{Characterizations of the sorbent}

As determined by EDAX, the predominant chemical composition of sewage sludge ash is given in Table1. These results showed that the predominant chemical compositions of this ash sample include silicon oxide, aluminum oxide, calcite and other oxides are present in trace amounts. It is thus expected that $\mathrm{Cd}$ (II) and $\mathrm{Ni}$ (II) would be mostly adsorbed either by silica, alumina or by a combined influence of these oxides. In addition, the cadmium and nickel content in sewage sludge is under the detection limit. For this reason, the effect of cadmium and nickel ions, released from sewage sludge into solutions, can be ignored in the following experiments.

Table 1. Chemical composition of sewage sludge ash.

\begin{tabular}{|c|c|c|c|c|c|c|c|c|c|c|c|c|c|c|}
\hline \multirow[t]{3}{*}{ Samples } & \multicolumn{14}{|c|}{ Composition } \\
\hline & \multicolumn{9}{|c|}{$(\%)$} & \multicolumn{5}{|c|}{ (mg/kg) } \\
\hline & $\mathrm{SiO}_{2}$ & $\mathbf{A l}_{2} \mathbf{O}_{3}$ & $\mathrm{CaO}$ & $\mathrm{Fe}_{2} \mathrm{O}_{3}$ & $\mathrm{SO}_{3}$ & $\mathbf{P}_{2} \mathbf{O}_{5}$ & $\mathrm{~K}_{2} \mathrm{O}$ & MgO & $\mathrm{Na}_{2} \mathrm{O}$ & Cd & $\mathbf{C u}$ & $\mathrm{Ni}$ & $\mathbf{P b}$ & $\mathbf{Z n}$ \\
\hline $\begin{array}{l}\text { Sewage } \\
\text { sludge ash }\end{array}$ & 19.95 & 9.02 & 20.98 & 2.07 & 9.00 & 16.6 & 23.05 & 2.47 & 0.92 & $-{ }^{a}$ & 0.28 & $-^{a}$ & 0.1 & 1.2 \\
\hline
\end{tabular}

X-ray diffraction analysis results of sewage sludge samples before and after heating for two hours at $600^{\circ} \mathrm{C}$ are presented in Fig. 1. We notice that the increase in temperature definitely increases the level of mineralization since more peaks appear. In the case of materials obtained at $600^{\circ} \mathrm{C}$, the degree of mineralization is much higher. The sample of sewage sludge dried at $105^{\circ} \mathrm{C}$ is predominantly amorphous. Combustion at $600^{\circ} \mathrm{C}$ results in formation of aluminosilicates, calcite and the oxides of aluminum, iron, magnesium, sodium and potassium (Brendel, 1995). The scanning electron microscope (SEM) image, as shown in Fig. 2, indicate the common

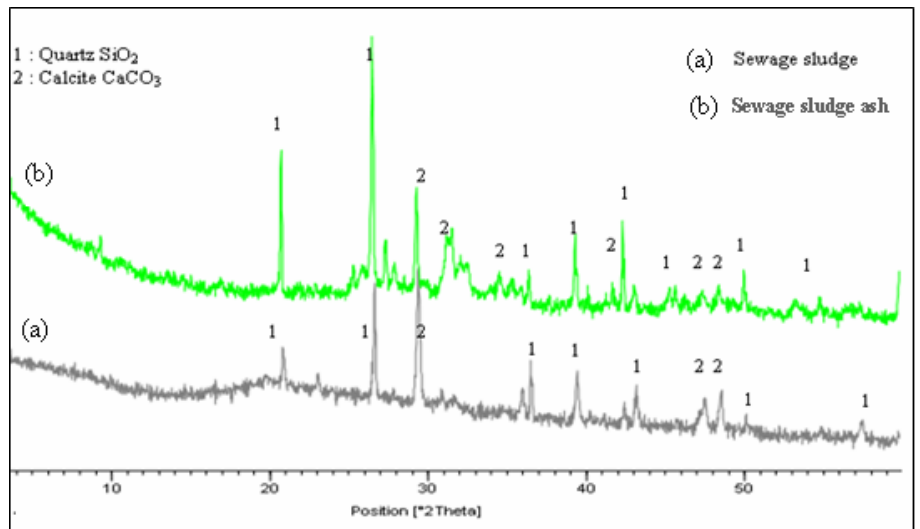

Figure 1. X-ray diffraction patterns of sewage sludge (a) before and (b) after combustion at $600^{\circ} \mathrm{C}$

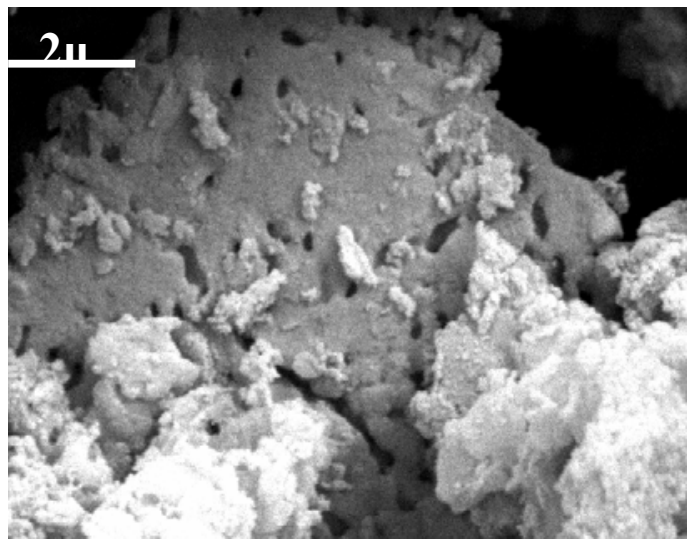

Figure 2. Scanning electron micrograph of sewage sludge ash.

feature of porous and irregular morphology of sewage sludge ash.

\section{Effect of agitation time on adsorption}

The agitation time was evaluated as one of the most important factors affecting the adsorption efficiency. The rate of uptake of metal ions by sewage sludge ash increases with time initially. 
The optimum time for both cadmium and nickel removal were determined at 120 min (Fig. 3). As a result of the experimental studies, it is seen that high efficiency for cadmium and nickel adsorption can be obtained at short time periods.

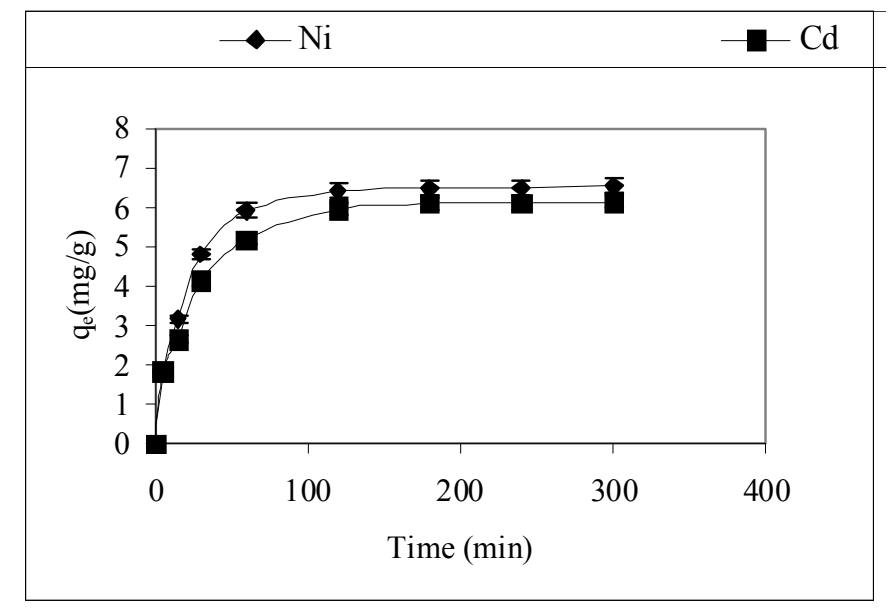

Figure 3. Effect of contact time on the removal of $\mathrm{Cd}^{2+}$ and $\mathrm{Ni}^{2+}$ ions by sewage sludge ash.

\section{Effect of pH}

The $\mathrm{pH}$ of the solution has a significant impact on the uptake of metal ions, since it determines the surface charge of the adsorbent, and the degree of ionization and speciation of the adsorbate. The $\mathrm{pH}$-adsorption edges of the constant concentration of $\mathrm{Ni}$ (II) and $\mathrm{Cd}$ (II) for a constant sorbent dose at $20^{\circ} \mathrm{C}$ are shown in Fig. 4. All experiments were carried out in the $\mathrm{pH}$ range of 2.0-8.0 where chemical precipitation is avoided, so that metal removal could be related to the adsorption process. As shown in Fig. 4, the maximum adsorption of $\mathrm{Ni}(\mathrm{II})$ and $\mathrm{Cd}$ (II) was found to occur at $\mathrm{pH} 6$ and the metal ions removal was nearly constant for $\mathrm{pH}>6$. This may be attributed to the surface charge development of the sewage sludge ash and the concentration distribution of metal ions since both of them are $\mathrm{pH}$-dependent (Bayat, 2002). The $\mathrm{pH}$ value of IEP where zero zeta potential occurs is defined as pHzpc. A pHzpc of 2.2 was obtained for sewage sludge ash. For pure oxides, such as silica, alumina, and ferric oxides pHzpc values are 2.0, 6.7, and 8.5, respectively (Huang and Rhoads, 1989; Stumm and Morgan, 1995). It is speculated that the lower pHzpc value of sewage sludge ash particles is attributed to high silica content (table.1) versus that of alumina and ferric oxides. Ni(II) and Cd(II) ion adsorption on sewage sludge ash may be attributed to the interaction with surface silica sites with only small contribution from the alumina and iron sites.

In aqueous solution, surface charge developed from the hydration is an important first step for metal adsorption. Since sewage sludge ash has a low pHzpc, negatively charged surface should be expected under the $\mathrm{pH}$ range investigated. It is noted that the sharply increasing adsorption is in the region of $\mathrm{pH} 3-6$. According to the simple species diagrams which were constructed for $\mathrm{Ni}(\mathrm{II})$ and $\mathrm{Cd}(\mathrm{II})$, all the species occurring at $\mathrm{pH}$ values of 6 and below would be $\mathrm{Ni}^{2+}$ and $\mathrm{Cd}^{2+}$, respectively, (Snoeyink and Jenkins, 1980; Mavros et al., 1993). As pH increased from 3-6, it is expected that sewage sludge ash surface became more negatively charged. Thus more favorable electrostatic attraction forces enhanced cationic metal ions adsorption as $\mathrm{pH}$ increased. Similar influence of $\mathrm{pH}$ has been previously reported for $\mathrm{Ni}(\mathrm{II})$ and $\mathrm{Cd}(\mathrm{II})$ adsorption onto bagasse fly ash (Srivastava et al., 2006). 


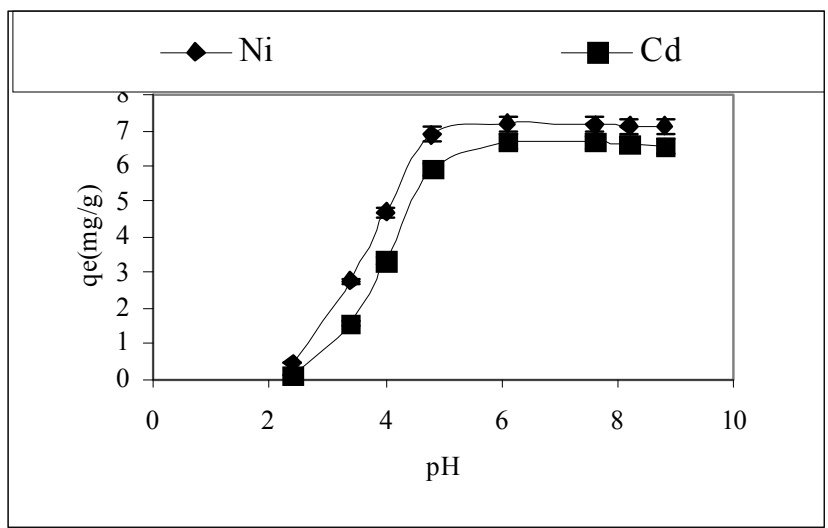

Figure 4. Effect of $\mathrm{pH}$ on the removal of $\mathrm{Ni}^{2+}$ and $\mathrm{Cd}^{2+}$ by sewage sludge ash

\section{Sorption isotherms}

Sorption isotherms of $\mathrm{Cd}^{2+}$ and $\mathrm{Ni}^{2+}$ ions are shown in Fig. 5. The adsorption data were described using the Langmuir and Freundlich isotherm models. The results of these analyses, using linear regression procedures, are shown in Table 2.

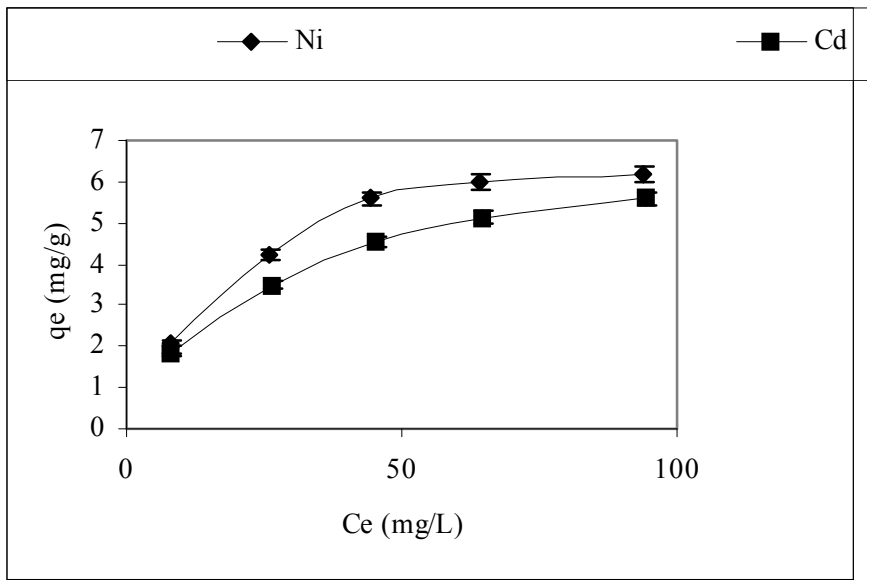

Figure 5. $\mathrm{Ni}(\mathrm{II})$ and $\mathrm{Cd}(\mathrm{II})$ adsorption isotherm on sewage sludge ash at $20^{\circ} \mathrm{C}$.

\section{$\underline{\text { Langmuir isotherm }}$}

Table 2 indicates that Langmuir model has a good fit with the experimental data for cadmium and nickel adsorption with a regression coefficient, $\mathrm{R}^{2}$ equal to 0.99 and 0.98 , respectively. Using the Langmuir model, the maximum adsorption capacity for the metals can be estimated as: $\mathrm{Ni}(7.65 \mathrm{mg} / \mathrm{g})$ and $\mathrm{Cd}(7.1 \mathrm{mg} / \mathrm{g})$.

\section{Freundlich isotherm}

Table 2 indicates that there is a slight deviation from linearity using the Freundlich isotherm model for describing $\mathrm{Ni}^{2+}$ and $\mathrm{Cd}^{2+}$ sorption $\left(\mathrm{R}^{2}\right.$ equal to 0.95 and 0.98 , respectively). Freundlich parameters $\left(\mathrm{k}_{\mathrm{F}}\right.$ and $\left.\mathrm{n}\right)$ indicate whether the nature of sorption is either favourable or unfavourable (Frimmel and Huber, 1996). The intercept is an indicator of sorption capacity and the slope is an indicator of sorption intensity. In the two sorption systems, values obtained of $1<\mathrm{n}<10$ imply favourable sorption. The $\mathrm{k}_{\mathrm{F}}$ values, reported in Table 2, can be used to indicate the relative adsorption capacity of the system (Mohan and Singh, 2002). It was noted that $\mathrm{k}_{\mathrm{F}}$ values show the same trend as that of $\mathrm{q}_{\max }$ for the metals studied (Table 2). 
Table 2. Freundlich and Langmuir constants for $\mathrm{Ni}$ (II and $\mathrm{Cd}(\mathrm{II})$ adsorption in single and binary-system on sewage sludge ash at $20^{\circ} \mathrm{C}$.

\begin{tabular}{|c|c|c|c|c|c|c|c|c|}
\hline & \multicolumn{3}{|c|}{ Langmuir model } & \multirow[b]{2}{*}{$\mathbf{q}_{\text {mix }} \mathbf{q}_{\text {max }}$} & \multicolumn{3}{|c|}{ Freundlich model } \\
\hline & & $q_{\max }(m g / g)$ & $\begin{array}{c}\text { b } \\
(\mathrm{L} / \mathrm{mg})\end{array}$ & $\mathbf{R}^{2}$ & & $\mathbf{K}_{\mathbf{f}}$ & $1 / \mathbf{n}$ & $\mathbf{R}^{2}$ \\
\hline \multicolumn{2}{|c|}{ Ni (single-metal) } & 7.65 & 0.051 & 0.99 & - & 0.87 & 0.45 & 0.95 \\
\hline \multicolumn{2}{|c|}{ Cd (single-metal) } & 7.1 & 0.039 & 0.98 & - & 0.69 & 0.47 & 0.93 \\
\hline \multirow[b]{3}{*}{ Ni-Cd } & {$[C d]=30 \mathrm{mg} / \mathrm{L}$} & 7.19 & 0.036 & 0.99 & 0.93 & 0.67 & 0.48 & 0.96 \\
\hline & {$[\mathrm{Cd}]=50 \mathrm{mg} / \mathrm{L}$} & 6.03 & 0.026 & 0.99 & 0.78 & 0.35 & 0.55 & 0.94 \\
\hline & {$[\mathrm{Cd}]=100 \mathrm{mg} / \mathrm{L}$} & 4.12 & 0.025 & 0.98 & 0.53 & 0.22 & 0.55 & 0.94 \\
\hline \multirow[b]{3}{*}{ Cd-Ni } & {$[\mathrm{Ni}]=30 \mathrm{mg} / \mathrm{L}$} & 6.98 & 0.025 & 0.99 & 0.98 & 0.38 & 0.57 & 0.95 \\
\hline & {$[\mathrm{Ni}]=50 \mathrm{mg} / \mathrm{L}$} & 5.98 & 0.022 & 0.99 & 0.84 & 0.19 & 0.67 & 0.93 \\
\hline & {$[\mathrm{Ni}]=100 \mathrm{mg} / \mathrm{L}$} & 4.93 & 0.018 & 0.98 & 0.69 & 0.07 & 0.75 & 0.93 \\
\hline
\end{tabular}

\section{Competitive adsorption in binary metal system}

In this group of experiments, competitive adsorption of $\mathrm{Cd}^{2+}$ and $\mathrm{Ni}^{2+}$ ions from their binary solutions was investigated by following a similar procedure as described above. These studies were performed at an initial $\mathrm{pH}$ of 6.0 at $20^{\circ} \mathrm{C}$. The experiments of competitive adsorption of $\mathrm{Cd}^{2+}$ and $\mathrm{Ni}^{2+}$ included the effect on adsorption of $\mathrm{Cd}^{2+}$ with the presence of $\mathrm{Ni}^{2+}$ in the solution, and the effect on adsorption of $\mathrm{Ni}^{2+}$ with the presence of $\mathrm{Cd}^{2+}$ in the solution. The objective of this part of work was to study the effect of two metal ions coexistence on the total adsorptive capacity of sewage sludge ash. The result was shown in Fig. $6 \mathrm{a}$ and $6 \mathrm{~b}$.

As shown in figure 6, values of the amount of metal ions adsorbed $\mathrm{q}_{\mathrm{e}}$ obtained from the experiment results for the binary component system at described conditions (the $\mathrm{pH}$ of the solutions was maintained at 6 for cadmium and nickel, $0.1 \mathrm{~g}$ of sorbent per $100 \mathrm{~mL}$ of solution at $20^{\circ} \mathrm{C}$ ) were ranging from 5.6 to $2.9 \mathrm{mg} / \mathrm{g}$ and 4.92 to $2.25 \mathrm{mg} / \mathrm{g}$ for $\mathrm{Ni}^{2+}$ and $\mathrm{Cd}^{2+}$, respectively, which were less than those for the single-component solutions $\left(6.2 \mathrm{mg} / \mathrm{g}\right.$ for $\mathrm{Ni}^{2+}$ and $5.6 \mathrm{mg} / \mathrm{g}$ for $\left.\mathrm{Cd}^{2+}\right)$. However, the total amount for these two metals in binary system was less than this in single-component systems. One type of the metal ion present interfered with the uptake of another one in the system, and the overall total metal uptake was lower than that in single system. 

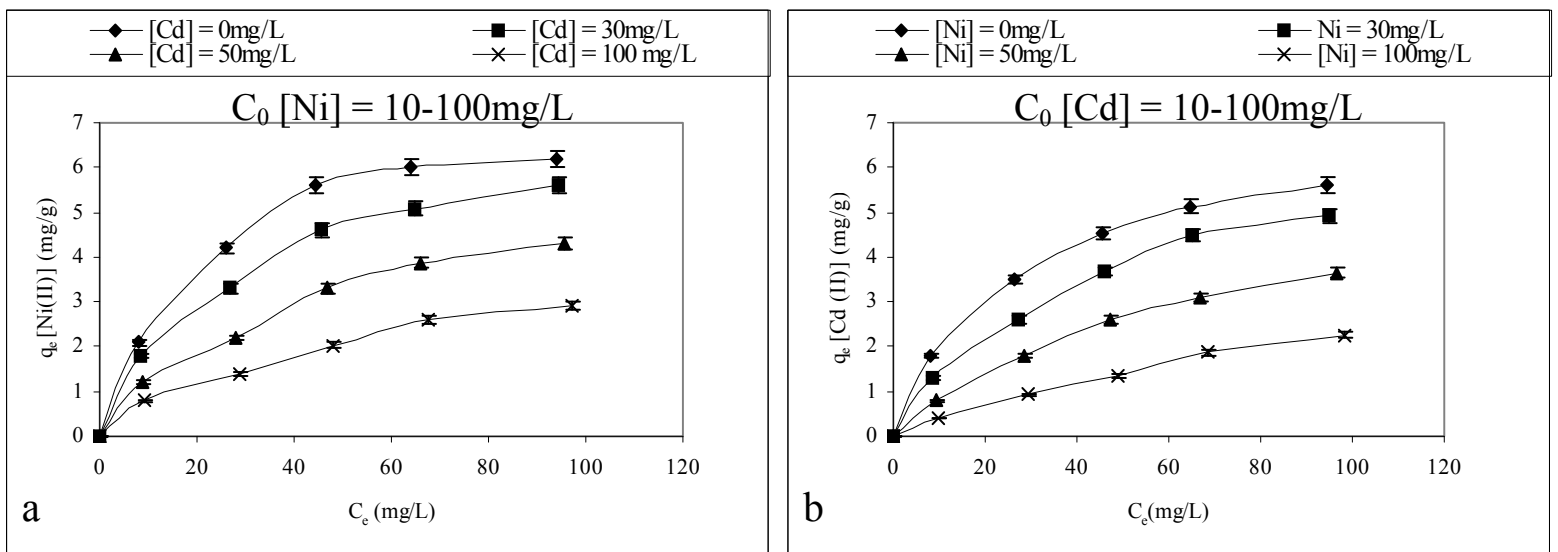

Figure 6. Comparison of non-linearized adsorption isotherms of (a) $\mathrm{Ni2}+$ ion in the presence of increasing concentration of $\mathrm{Cd}^{2+}$ ion $\left(\mathrm{pH}=6, \mathrm{~T}=20^{\circ} \mathrm{C}, \mathrm{t}=2 \mathrm{~h}, \mathrm{CO}[\mathrm{Ni}]=10-100 \mathrm{mg} / \mathrm{L}\right)$ and $(\mathrm{b}) \mathrm{Cd}^{2+}$ ion in the presence of increasing concentration of $\mathrm{Ni}^{2+}$ ion $\left(\left(\mathrm{pH}=6, \mathrm{~T}=20^{\circ} \mathrm{C}, \mathrm{t}=2 \mathrm{~h}, \mathrm{CO}[\mathrm{Cd}]=10-100 \mathrm{mg} / \mathrm{L}\right)\right.$.

The Langmuir model yielded best fit for $\mathrm{Ni}$ and $\mathrm{Cd}$ sorption on sewage sludge ash in single- as well as in binary-systems (figure 6). The fitting parameters of $\mathrm{Ni}$ and $\mathrm{Cd}$ in binary system are tabulated in Table 2. When compared with their adsorption in single-solute systems, the individual adsorption capacity of all the two metals showed obvious decrease in binary solute systems. These results indicated a competition between metals for sorption sites.

The competitive effects between $\mathrm{Ni}$ and $\mathrm{Cd}$ in the binary system could be represented by the ratio of the maximum sorption capacity for the metal in the binary-metal system $\left(\mathrm{q}_{\text {mix }}\right)$ to the maximum sorption capacity for the same metal in the single-metal system $\left(q_{\max }\right)$. When the value of the ratio is greater than one, the sorption is promoted by the presence of the other metals; when $\mathrm{q}_{\operatorname{mix}} / \mathrm{q}_{\max }=1$ no competitive effects are observable; when the value of the ratio is less than one, the sorption is reduced by the presence of other metal ions (Mohan and Singh, 2002). Our values of the ratio (Table 1) were less than one, confirming the effects of the competitive sorption in the binary-metal system.

\section{CONCLUSION}

The results obtained in this study clearly demonstrated the potential use of sewage sludge ash for the removal of $\mathrm{Ni}$ (II and $\mathrm{Cd}$ (II) from aqueous solutions. The following conclusions can be drawn based on the investigation:

1. The kinetic studies indicated that equilibrium in the adsorption of $\mathrm{Ni}$ (II and $\mathrm{Cd}(\mathrm{II})$ on sewage sludge ash was reached in $2 \mathrm{~h}$.

2. The optimum $\mathrm{pH}$ corresponding to the maximum adsorption was found to be 6 .

3. Langmuir isotherm better fitted the experimental data since the correlation coefficients for Langmuir isotherm was higher than the Freundlich isotherm for both metals.

4. Adsorption of metal ions onto sewage sludge ash is favourably influenced by an increase in the temperature of the operation. The enhanced sorption at higher temperature indicates endothermic adsorption process.

5. In the binary metal mixtures, the affinity of the sewage sludge ash for $\mathrm{Ni}(\mathrm{II})$ ions was greater than that for $\mathrm{Cd}(\mathrm{II})$, from both single-component and the binary solutions under the same experimental conditions.

6. The experimental studies showed that sewage sludge ash could be used as an alternative, inexpensive and effective material to remove high amount of toxic $\mathrm{Ni}(\mathrm{II})$ and $\mathrm{Cd}(\mathrm{II})$ ions from wastewaters. 


\section{REFERENCES}

- Adriano, D.C., Page, A.L., Elseewi, A.A, Chang, A.C., Straughan, I., 1980. Utilization and disposal of fly ash and other coal residues in terrestrial ecosystems: a review. J. Environ. Qual. 9, 333-344.

- ATSDR, Draft toxicological profile for nickel, Agency for toxic substances and disease registry, U.S. Department of health and human services, Atlanta, Georgia, 2003.

- Bagreev, A., Bashkova, S., David, C., Bandosz, T.J., 2001. Sewage sludge-derived materials as efficient adsorbents for removal of hydrogen sulfide J. Environ. Sci. Technol. 35, 1537-1543.

- Bashkova, S., Bagreev, A., David, C., Bandosz, T.J., 2001. Adsorption of SO2 on sewage sludgederived materials J. Environ. Sci. Technol. 35, 3263-3269.

- Beaver T., 1995. Adding coal ash to the composting mix. Biocycle 36, 88-89.

- Boonfueng, T., Axe, L., Xu, Y., Tyson, T.A., 2006. Nickel and lead sequestration in manganese oxide-coated montmorillonite, J. Colloid Interf. Sci. 303, 87-98

- Bouzid, J., Elouear, Z., Ksibi, M., Feki, M., Montiel, A., 2008. A study on removal characteristics of copper from aqueous solution by sewage sludge and pomace ashes. J. Hazard. Mater.152, 838845 .

- Brendel, GF., In: 11th international symposium on use and management of coal combustion byproducts, Orlando FL, USA, 1995.

- Cho, H., Oh, D., Kim, K. 2005. A study on removal characteristics of heavy metals from aqueous solution by fly ash. J. Hazard. Mater. 127,187-195.

- Chiang, P.C., You, J.H., 1987. Use of sewage sludge for manufacturing adsorbents. Can. J. Chem. Eng. 65, 922.

- Eiceman, G.A., Vandiver, V.J., 1983. Adsorption of polycyclic aromatic hydrocarbons on fly ash from a municipal incinerator and a coal-fired power plant. Atmos. Environ. 17, 461-465.

- Elseewi, A.A., Straughan, I.R., Page, A.L., 1980. News section. Sci. Total Environ. 15, 275-276.

- Frimmel, F.H., Huber, L., 1996. Influence of humic substances on the aquatic sorption of heavy metals on defined minerals phases. Environ. Int. 22, 507-517.

- Glasstone, S., 1981.Text Book of Physical Chemistry, second ed., Macmillan, India.

- Huang C.P, Rhoads, E.A., 1989. Adsorption of Zn(II) onto hydrous aluminosilicates. J. Colloid Interf. Sci. 131, 289-306.

- Kadirvelu, K., Thamaraiselvi, K., Namasivayam, C., 2001. Adsorption of nickel(II) from aqueous solution onto activated carbon prepared from coirpith, Sep. Pur. Technol. 24, 497- 505.

- Kadirvelu, K., Namasivayam, C., 2003. Activated carbon from coconut coirpith as metal adsorbent: adsorption of Cd(II) from aqueous solution. Adv. Environ. Res. 7, 471- 478.

- Kao, P.C., Tzeng, J.H., Huang, T.L., 2000. Removal of chlorophenols from aqueous solution by fly ash. J. Hazard. Mater. 76, 237-249.

- Karabulut, S., Karabakan, A., Denizli, A., Yurum, Y., 2000. Batch removal of copper(II) and zinc(II) from aqueous solutions with low-rank Turkish coals. Sep. Purif. Technol. 18, 177- 184.

- Kumar, K.V., Ramamurthi, V., Sivanesan, S., 2005. Modeling the mechanism involved during the sorption of methylene blue onto fly ash. J. Colloid Interf. Sci. 284,14-21.

- Low, K.S., Lee, C.K., Leo, A.C., 1995. Removal of metals from electroplating wastes using banana pith, Bioresource. Technol. 51, 227- 231.

- Lin, C.F., His H.C., 1995. Resource recovery of waste fly ash: synthesis of zeolite-like materials. Environ Sci. Technol. 29, 1109-1117.

- Malandrino, M., Abollino, O., Giacomino, A., Aceto, M., Mentasti, E., 2006. Adsorption of heavy metals on vermiculite: Influence of $\mathrm{pH}$ and organic ligands. J. Colloid Interf. Sci. 299, 537- 546

- Mavros, P., Zouboulis, A.I., Lazaridis, N.K, 1993. Removal of metal ions from wastewaters. The case of nickel. J. Environ. Technol. 14, 83-91.

- Mohan, D., Singh, K.P., 2002. Single- and multi-component sorption of cadmium and zinc using activated carbon derived from bagasse-an agricultural waste. Water Res. 36, 2304-2318.

- Pan, S.C., Lin, C.C., Tseng, D. H., 2003. Reusing sewage sludge ash as adsorbent for copper removal from wastewater. Resour Conserv. Recy. 39, 79-90. 
- $\quad$ Pratt, PL., 1990. Material Research Society, Pittsburgh, PA, USA, p.177.

- Sarioglu, M., Atay, Ü.A., Cebeci, Y., 2005. Removal of copper from aqueous solutions by phosphate rock. Desalination. 181, 303-311.

- Snoeyink, V.L, Jenkins, D., 1980. Water Chemistry, John Wiley and Sons, New York,

- Srivastava, V.C., Mall, I.D., Mishra, I.M., 2006. Characterization of mesoporous rice husk ash (RHA) and adsorption kinetics of metal ions from aqueous solution onto RHA. J. Hazard. Mater. 134, 257-267.

- Srivastava, V.C., Mall, I.D., Mishra, I.M.. 2006. Equilibrium modelling of single and binary adsorption of cadmium and nickel onto bagasse fly ash. Chem. Eng. J. 117, 79-91.

- Stumm, W., Morgan, J.J., 1995. Aquatic Chemistry, Wiley, New York, 1995.

- Vincini, M., Carini, F., Silva, S., 1994. Use of alcaline fly ash as an amendment for swine manure. Biosour. Technol. 49, 213-222.

- Wang, S., Wu, H., 2006. Environmental-benign utilisation of fly ash as low-cost adsorbents. J. Hazard. Mater. 136, 482-501.

- Wilson, A.R., Lion, L.W., Nelson, Y.M., 2001. Pb scavenging from a freshwater lake by Mn oxides in heterogeneous surface coating materials. Environ. Sci. Technol. 35, 3182-3189.

WWW_YES-Elouar-Paper-2010-04-08-edited.doc 